\title{
Ekspplorasi Etnomatematika pada Aktivitas Membatik di Rumah Produksi Batik Dewi Sinta Banyuwangi Sebagai Bahan Ajar Siswa Kelas VII
}

Author:
Rislatul Badiah ${ }^{1}$
Dinawati Trapsilasiwi ${ }^{2}$
Susi Setiawani $^{3}$
Ferry Kurnia Putra $^{4}$
Nida'an Chofiyyah Astari $^{5}$

Affiliation:
${ }^{1,2,3}$ University of Jember, East
Java, Indonesia
${ }^{4}$ SMA Negeri 1 Jember, East
Java, Indonesia
${ }^{5}$ MTs Al-Islamiyah Lumajang,
East Java, Indonesia
Corresponding author:
Rislatul Badiah,
rislatulbadiah@gmail.com
Dates:
Received: $27 / 2 / 2021$
Accepted: $10 / 3 / 2021$
Published: $16 / 3 / 2021$

\begin{abstract}
Abstrak. Matematika merupakan salah satu ilmu yang sering digunakan dalam bidang kebudayaan. Bentuk kegiatan budaya yang mengandung konsep matematika disebut etnomatematika. Matematika yang berkaitan dengan budaya akan memudahkan siswa dalam proses pembelajaran. Tujuan dari penelitian ini adalah untuk mengetahui dan mendeskripsikan etnomatematika pada kegiatan membatik pada Produksi Batik Dewi Sinta Banyuwangi dan sebagai bahan lembar kerja siswa. Jenis penelitian ini adalah penelitian kualitatif dengan pendekatan etnografi. Pengumpulan data dilakukan melalui observasi dan wawancara. Subjek penelitian adalah pemilik dan karyawan pada Bagian Produksi Batik Dewi Sinta Banyuwangi. Penelitian ini menggunakan analisis data deskriptif kualitatif. Hasil penelitian ini menunjukkan bahwa terdapat konsep matematika pada kegiatan membatik pada Batik Production Batik Dewi Sinta Banyuwangi yang meliputi kegiatan berhitung, menghitung, mengukur, dan merancang. Produk penelitian ini berupa bahan ajar berupa LKS kelas VII yang berisi tentang etnomatematika dalam kegiatan membatik.
\end{abstract}

Kata kunci: Etnomatematika, aktivitas membatik, lembar kerja siswa

Abstract. Mathematics is one of the sciences that is often used in culture. Forms of cultural activities containing mathematical concepts are called ethnomatematics. Mathematics related to culture will make it easier for students in the learning process. The purpose of this research is to know and describe ethnomatematics on the activities of batik in Batik Production Batik Dewi Sinta Banyuwangi and as material for student worksheet. This type of research is qualitative research with ethnographic approach. The data were collected form observation and interview. The research subjects were owners and employees at the Batik Production Batik Dewi Sinta Banyuwangi. This research uses descriptive qualitative data analysis. This research showed that there were mathematical concepts on the activities of batik in Batik Production Batik Dewi Sinta Banyuwangi wich includes counting, calculating, measuring, and designing activities. The product of this research is a teaching material in the form of student worksheet for class VII which contains ethnomatematics in batik activity.

Keywords: Ethnomathematics, activity of batik, Students Worksheet

\section{Copyright:}

JoMEaL

This work is licensed under a Creative Commons Attribution-ShareAlike 4.0 International License.

Read online:

https://jurnal.unej.ac.id/index.php/JOMEAL/index or scan barcode beside.

How to cite this article:

Badiah, R., Trapsilasiwi, D., Setiawani, S., Putra, F., \& Astari, N. (2021). Eksplorasi Etnomatematika pada Aktivitas Membatik di Rumah Produksi Batik Dewi Sinta Banyuwangi Sebagai Bahan Ajar Siswa Kelas VII. Journal of Mathematics Education and Learning, 1(1), 63-72. Retrieved from https://jurnal.unej.ac.id/index.php/JOMEAL/ $\underline{\operatorname{article} / \mathrm{view} / 24376}$ 


\section{Pendahuluan}

Pendidikan merupakan salah satu hal yang wajib didapatkan oleh setiap individu, karena pendidikan memiliki peranan yang sangat penting bagi perkembangan setiap individu untuk menciptakan individu yang berkualitas. Salah satu materi yang didapatkan pada pendidikan formal adalah matematika. Matematika sebagai ilmu dasar yang memegang peranan penting dalam pengembangan sains dan teknologi, karena matematika merupakan sarana berpikir untuk menumbuhkembangkan daya nalar, cara berpikir logis, sistematis dan kritis (Hobri, 2008). Matematika juga tumbuh dan berkembang dengan sendirinya sebagai suatu ilmu yang menyediakan jasa layanan untuk pengembangan ilmu- ilmu lainnya (Soedjadi, 2000). Matematika dibagi menjadi beberapa cabang ilmu yaitu aljabar, aritmatika, geometri, trigonometri, dan kalkulus (Purba, 2014). Selain itu, tanpa disadari matematika sering digunakan dalam aktivitas kehidupan sehari-hari setiap individu, salah satunya dalam aspek kebudayaan. Oleh karena itu, matematika sangat penting untuk diajarkan sejak dini.

Hubungan antara matematika dengan kebudayaan dikenal dengan istilah etnomatematika. Etnomatematika adalah suatu studi tentang pola hidup, kebiasaan atau adat istiadat dari suatu masyarakat di suatu tempat yang memiliki kaitan dengan konsep- konsep matematika namun tidak disadari sebagai bagian dari matematika oleh masyarakat tersebut (Suwito \& Trapsilasiwi, 2016). Salah satu kebiasaan masyarakat yang dilakukan hingga saat ini adalah membatik. Batik merupakan salah satu warisan budaya Indonesia yang sampai saat ini masih dilestarikan dan berkembang serta diminati oleh berbagai kalangan. Setiap ragam hias batik mengandung nilai filosofi yang merupakan ungkapan cipta rasa dan karsa serta doa (Tjahjani, 2013). Namun budaya batik jarang dilihat dari sudut pandang matematika yang mengakibatkan kurangnya kesadaran masyarakat bahwa terdapat unsur matematika di dalam budaya batik. Salah satu perusahaan yang memproduksi batik hingga saat ini adalah Rumah Produksi Batik Dewi Sinta Banyuwangi.

Berdasarkan uraian di atas maka akan dilakukan penelitian bagaimana aktivitas membatik yang dilakukan oleh pembatik di Rumah Produksi Batik Dewi Sinta Banyuwangi dengan tujuan untuk mengungkapkan konsep matematika yang terdapat pada aktivitas membatik di Rumah Produksi Batik Dewi Sinta. Konsep matematika yang terdapat pada aktivitas membatik tersebut akan dijadikan bahan untuk membuat Lembar Kerja Siswa (LKS). Lembar Kerja Siswa (LKS) adalah media cetak yang berupa lembaran kertas yang berisi informasi soal/pertanyaan yang harus diselesaikan oleh siswa (Lestari, 2013).

Penelitian ini membahas mengenai etnomatematika pada aktivitas membatik di Rumah Produksi Batik Dewi Sinta Banyuwangi mengenai konsep matematika yang meliputi aktivitas membilang, mengukur, menghitung, dan mendesain. Hasil dari penelitian ini kemudian dijadikan bahan untuk membuat LKS dengan pokok bahasan perbandingan untuk kelas VII.

\section{Metode Penelitian}

Pada penelitian ini metode yang digunakan adalah kualitatif dengan pendekatan etnografi. Pendekatan etnografi pada penelitian ini digunakan untuk menggambarkan, menjelaskan dan menganalisis konsep-konsep matematika yang terdapat pada aktivitas membatik di Rumah Produksi Batik Dewi Sinta Banyuwangi.

Terdapat beberapa tahapan yang dilakukan dalam proses penelitian ini. Tahap pertama yaitu pendahuluan. Pendahuluan dilakukan dengan observasi awal di Rumah Produksi Batik Dewi Sinta 
Banyuwangi untuk menetapkan fokus penelitian. Tahap kedua adalah membuat instrumen penelitian yang terdiri dari instrumen observasi dan instrumen wawancara. Tahap selanjutnya yaitu validasi instrumen. Validasi intrumen dilakukan oleh dua dosen pendidikan matematika, Instrumen dapat digunakan pada tahap selanjutnya jika instrumen dinyatakan valid, tetapi jika instrumen dinyatakan tidak valid maka akan dilakukan revisi dan validasi ulang. Tahap keempat adalah pengumpulan data, yang dilakukan dengan observasi dan wawancara. Observasi dilakukan dengan cara mengamati aktivitas membatik di Rumah Produksi Batik Dewi Sinta Banyuwangi, dan wawancara dilakukan dengan cara mewawancarai subjek penelitian yang terdiri dari 5 orang karyawan di Rumah Produksi Batik Dewi Sinta Banyuwangi. Tahap kelima adalah melakukan analisis data. Analisis data dilakukan dengan cara mengelompokkan data dari hasil pengumpulan data serta menyusun data sesuai fokus kajian masalah dan tujuan penelitian. Tahapan selanjutnya adalah membuat bahan ajar dalam bentu Lembar Kerja Siswa dari hasil penelitian etnomatematika pada aktivitas membatik di rumah roduksi Batik Dewi Sinta Banyuwangi. LKS tersebut kemudian divalidasi oleh validator yang terdiri dari dua dosen pendidikan matematika. Tahapan terakhir yaitu penarikan kesimpulan dari analisis data yang telah dilakukan.

\section{Hasil dan Pembahasan}

Salah satu perusahaan yang memproduksi batik khususnya batik Banyuwangi hingga saatini adalah Rumah Produksi Batik Dewi Sinta Banyuwangi. Berdasarkan hasil observasi dan wawancara dari subjek penelitian, terdapat aktivitas matematika yang terdapat pada aktivitas membatik diantaranya aktivitas membilang, menghitung, mengukur, dan mendesain.

\section{Aktivitas Membilang}

Aktivitas membilang terlihat pada aktivitas membatik dalam menyiapkan alat dan bahan, membuat pola atau motif batik, menulisi pola atau motif dengan malam menggunakan canting, proses pewarnaan, serta proses penguncian warna dan pelorodan. Berdasarkan hasil penelitian, aktivitas membilang muncul ketika pembatik menyebutkanjumlah bilangan dan satuan untuk menyatakan ukuran bahan.. Pembatik menyebutkan yard dan centimeter $(\mathrm{cm})$ sebagai satuan panjang kain dan satuan pengukuran panjang garis tepi yang harus digambar pada kain, kilo yang berarti kilogram $(\mathrm{kg})$ sebagai satuanuntuk menyatakan berat malam dan pewarna, liter sebagai satuan yang digunakan untukmenyatakan volume waterglass, mili yang berarti miliiter (ml) digunakan untuk menyatakan volume pewarna yang digunakan, satu toples untuk menyatakan banyaknyawaterglass, serta gram (gr) merupakan satuan yang digunakan untuk menyatakan berat pewarna bubuk yang digunakan pada proses pewarnaan. Berdasarkan hal tersebut, etnomatematika yang terdapat pada aktivitas menyebutkan jumlah bilangan dan satuan adalah membilang. Hal ini sejalan dengan penelitian yang dilakukan oleh Rohma (2018)yang menunjukkan adanya unsur-unusr matematika yaitu membilang pada aktivitas membatik.

\section{Aktivitas Menghitung}

Menurut Fadlilah (2015) menghitung adalah mencari jumlahnya (sisanya, pedapatannya) dengan cara menjumlahkan, mengurangi, dan sebagainya (Lestari, 2013). Aktivitas menghitung terlihat ketika pembatik menghitung potongan kain dalam satu gulungan dengan panjang 50 yard.

$$
1 \mathrm{yard}=90 \mathrm{~cm}
$$




$$
\begin{aligned}
& 50 \text { yard }=50 \times 90=4500 \mathrm{~cm} \\
& 4500 \mathrm{~cm}: 20=225 \mathrm{~cm}
\end{aligned}
$$

Sehingga, pembatik dapat menghitung kebutuhan kain untuk membatik yaitu $225 \mathrm{~cm}$. Pembatik juga menghitung kebutuhan malam dan pewarna yang digunakan untuk membatik. Kebutuhan malam dan pewarna yang digunakan tergantung pada motif dan banyaknya jenis yang diinginkan. berdasarkan wawancara, pembatik membutuhkan $\pm 2 \mathrm{~kg}$ malam untuk mencanting. Berdasarkan hal ini, etnomatematika yang munculketika pembatik menghitung kebutuhan malam dan pewarna adalah perbandingan senilai. Aktivitas menghitung juga terlihat ketika pembatik menghitung banyaknya motif pada kain. Subjek mengatakan motif utama yang digunakan pada kain berjumlah 4 dandapat dikombinasikan dengan 2 sampai 3 motif lainnya, sehingga perhitungan banyaknya motif pada satu lembar kain adalah $4 \times 1=4$. Berdasarkan hal tersebut, maka etnomatematika yang terdapat pada aktivitas menghitung banyaknya motif adalah operasi hitung. Aktivitas menghitung juga terkihat ketika pembatik menghitung banyaknya malam yang diambil menggunakan canting. Malam yang diambil menggunakan canting harus sedikit agar malam tidak tumpah dan menyebar atau membeku pada canting. Setelah diukur volume malam yang diambil menggunakan canting tersebut $\pm 0,7 \mathrm{ml}$.

Aktivitas menghitung terlihat ketika pembatik menghitung pencampuran warna utama untuk membuat warna baru. Misalkan pembatik menginginkan warna hijau muda pembatik mencampurkan setengah botol pewarna kuning dengan setengah botol pewarna biru, maka perbandingan warna kuning dan biru adalah 1:1. Pembatik juga mencampurkan $1 \mathrm{~kg}$ bahan alam dengan 6 liter air untuk membuat pewarna alami, maka perbandingan bahan alam dengan air yang digunakan adalah 1:6. Etnomatematika yang muncul pada aktivitas ini adalah perbandingan. Aktivitas menghitung selanjutnya muncul ketika pembatik menentukan banyaknya pencelupan kain batik pada pewarna. Batik tulis dengan pewarna kimia memerlukan hanya 1 kali pencelupan, sedangkan batik tulis dengan pewarna alami membutuhkan hingga 10 kali pencelupan. Berdasarkan hal tersebut, etnomatematika yang muncul ketika pembatik menentukan banyaknya pencelupan adalah operasi hitung. Aktivitas menghitung juga muncul ketika pembatik menentukan banyaknya kebutuhan waterglass. Banyak waterglass yang dibutuhkan memiliki aturan, yaitu 3 liter waterglass dicampur dengan 1 liter air atau dengan perbandingan 3:1. Berdasarkan hal itu, etnomatematika yang terdapat pada aktivitas menentukan banyaknya waterglass adalah perbandingan.

\section{Aktivitas Mengukur}

Aktivitas mengukur adalah aktivitas matematika yang terkait dengan penggunaan alat ukur yang sering digunakan (Wahyuni, 2016). Aktivitas mengukur juga terlihat pada aktivitas membatik. Berdasarkan wawancara aktivitas mengukur terlihat ketika proses pemotongan kain. Gulungan kain dengan panjang 50 yard $(1$ yard $=90 \mathrm{~cm}$ ) akan dilipat menjadi 20 bagian yang sama kemudian dipotong sesuai dengan lipatan, sehingga panjang kain yang dihasilkan $225 \mathrm{~cm}$. Selain itu pembatik mengukur garis tepi kain selebar tiga ruas jari, setelah diukur lebar garis tepi tersebut adalah $\pm 7 \mathrm{~cm}$ dari ujung kain. Hal itu menunjukkan etnomatematika yang terdapat pada aktivitas pemotongan kain adalah operasi hitung.

Aktivitas mengukur selanjutnya terlihat ketika pembatik menentukan jarak antar pola atau motif pada kain. Jarak antar pola atau motif pada kain yaitu $18 \mathrm{~cm}$. Agar tidak terjadi pemborosan pada kain untuk membuat kemeja subjek memanfaatkan lipatan- lipatan pada kain untuk menentukan 
letak motif yang disesuaikan dengan panjang kain, banyak motif, dan jarak antar motif sehingga letak motif pada kain simetris. Hal ini dilakukan agar motif pada kain mudah untuk disambungkan dari setiap ujung kain. Aktivitas mengukur juga terdapat pada saat mencanting adalah ketika pembatik menentukan ukuran canting yang digunakan pada setiap motif. Pemilihan ukuran lubang canting disesuaikan dengan ukuran ketebalan motif dan memanfaatkan alat bantu ukur yang tidak baku yaitu lidi. Ketebalan lidi disesuaikan dengan ukuran lubang canting dengan cara memasukkan lidi ke lubang canting. Hasil pengukuran yang telah dilakukan dijadikan sebagai ketetapan dalam kegiatan mencanting. Selanjutnya aktivitas mengukur terlihat ketika proses mencolet. Pembatik mencolet warna pada kain menggunakan ujung kuas. Motif dengan ukuran yang berbeda memiliki tingkat ketebalan spons yang berbeda. Ketebalan spons dengan satu ikat merupakan ukuran yang digunakan untuk motif dengan ukuran yang kecil, jika ketebalan motif lebih besar maka ketebalan spons juga bertambah menjadi dua ikat.

Aktivitas mengukur selanjutnya terlihat ketika pembatik mengambil air yang dibutuhkan untuk proses pelorodan. Proses ini bertujuan untuk menghilangkan malam yang menempel pada kain. Ukuran air yang dibutuhkan yaitu setengah dari wadah yang digunakan. Setelah diukur ternyata volume air yang digunakan adalah 140 liter, dan wadah yang digunakan memiliki ukuran volume 280 liter. Hal ini menunjukkan bahwa air yang digunakan pada proses pelorodan adalah setengah dari wadah yang digunakan. Kebutuhan air yang digunakan bergantung pada banyaknya kain, jika kain yang diproduksi banyak maka air yang dibutuhkan juga banyak. Berdasarkan hal itu etnomatematika yang muncul pada aktivitas menentukan banyaknya air adalah perbandingan senilai.

\section{Aktivitas Mendesain}

Menurut Fadlilah (2015) aktivitas mendesain adalah aktivitas yang dilakukan masyarakat yang berkaitan dengan kegiatan membuat rancang bangun yang memiliki fungsi tertentu. Pendesainan merupakan salah satu aktivitas yang berkaitan dengan matematika terapan dan aktivitas pendesainan yang dilakukan oleh masyarakat berkaitandengan kegiatan membuat rancang bangun telah diterapkan oleh semua jenis suku dan budaya (Hartoyo, 2012).

Aktivitas mendesain terlihat pada aktivitas membuat pola atau motif batik tulis. Terdapat beberapa konsep geometri pada aktivitas pembuatan pola atau motif batik tulisyang dihasilkan antara lain bangun datar dan transformasi geometri.

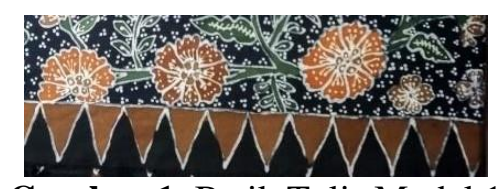

Gambar 1. Batik Tulis Model 1

Batik di atas merupakan salah satu contoh batik yang membuktikan adanya konsepbangun datar dan transformasi geometri pada bentuk motifnya. Konsep bangun datar yangterdapat pada motif batik tersebut adalah segitiga yang terdapat disepanjang tepi kain. Konsep transformasi geometri yang ditemukan antara lain translasi, refleksi, dan rotasi yang terdapat pada ornamen segitiga di sepanjang tepi kain. Konsep translasi terlihat pada ornamen segitiga yang berwarna hitam maupun coklat. Ornamen segitiga tersebut mengalami pergeseran posisi dengan jarak tertentu tanpa merubah ukuran dan bentuk. Konsep refleksi didapat dari ornamen segitiga yang memiliki daerah sama jika dibagi 
secara vertikal. Konsep rotasi terlihat pada ornamen segitiga coklat dan hitam, dimana ornamen segitiga coklat merupakan hasil perputaran $180^{\circ}$ dari ornamen segitiga hitam.

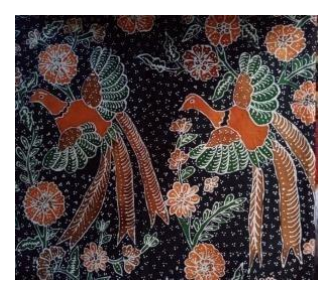

Gambar 2. Batik Tulis Model 2

Motif batik di atas membuktikan adanya konsep translasi atau pergeseran. Pembatikmenggabar motif pada kain dengan ornamen yang sama dan melakukan pergeseran motifdengan jarak tertentu. Ornamen burung tersebut mengalami pergeseran posisi dengan jarak tertentu serta tidak merubah ukuran dari ornamen burung tersebut.

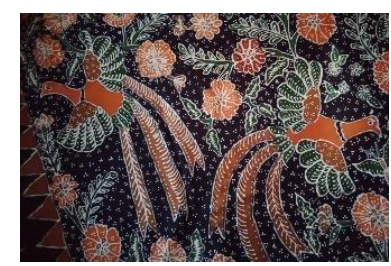

Gambar 3. Batik Tulis Model 3

Motif batik di atas juga menunjukkan adanya konsep tranformasi yaitu refleksi. Pembatik Ornamen burung tersebut telah direfleksikan terhadap sumbu Y tanpa mengubah ukuran dari ornamen burung itu sendiri. Hasil penelitian ini dapat dikaitkan dengan penelitian yang dilakukan oleh Isnawati (2017) yang menunjukkan adanya keterkaitan antara motif sulam usus denganmatematika pada konsep geometri. Penelitian lain yang dilakukan oleh Arwanto yang menunjukkan pada batik trusmi Cirebon mengandung unsur-unsur matematis, dianataranya adalah konsep-konsep geometri simetri, transformasi (refleksi, translasi, danrotasi), serta kekongruenan. Penelitian lain yang dapat dikaitkan dengan penelitian inidilakukan oleh Rohma (2018) yang menunjukkan adanya unsur-unusr matematika yaitumembilang, mengukur, dan menghitung pada aktivitas membatik. Aktivitas mattematikayang terdapat pada aktivitas membatik pada penelitian ini selanjutnya dijadikan sebagaibahan untuk membuat Lembar Kerja Siswa dengan menggunakan pendekatan scientific.

Lembar Kerja Siswa (LKS) yang dihasilkan berisi ringkasan materi dan aktivitasyang harus dilakukan siswa diantaranya mengamati, menganalisis, mencoba, danmengkomunikasikan. Lembar Kerja Siswa (LKS) dengan pokok bahasan perbandinganyang berdasarkan etnomatematika pada aktivitas membatik di Rumah Produksi BatikDewi Sinta Banyuwangi dapat diakses melalui tautan berikut. https://drive.google.com/file/d/1yiNcRJRKuyQUJ2c0zC5vh2PcmdltcKFw/view? usp=s haring

\section{Kesimpulan}

Berdasarkan hasil analisis dan pembahasan, dapat diambil kesimpulan bahwa pada aktivitas membatik di Rumah Produksi Batik Dewi Sinta Banyuwangi ditemukan konsep matematika yaitu 
aktivitas membilang, menghitung, mengukur, dan mendesain. Aktivitas membilang terlihat Ketika pembatik menyebutkan beberapa satuan untuk menyatakan ukuran bahan yang digunakan. Aktivitas menghitung terlihat ketika pembatik menghitung kebutuhan bahan yang digunakan untuk membatik, menentukan banyaknya pola atau motif yang digunakan pada kain, menghitung pencampuran warna utama untuk menghasilkan warna baru, dan ketika pembatik menentukan kebutuhan waterglass. Aktivitas mengukur terlihat ketika pembatik mengukur kain pada gulungan ketika proses pemotongan, menentukan jarak antar motif, ketika pembatik menentukan ukuran lubang canting yang digunakan untuk mencanting motif, dan ketika pembatik mengukur kebutuhan air yang digunakan pada proses pelorodan. Aktivitas mendesain terlihat ketika pembatik membuat pola atau motif batik tulis.

Etnomatematika yang terdapat pada aktivitas membatik tersebut kemudian dijadikan bahan pembuatan Lembar Kerja Siswa. Lembar Kerja Siswa (LKS) yang disusun digunakan untuk kelas VII dengan pokok bahasan perbandingan. LKS tersebut berisi kompetensi inti, kompetensi dasar, indikator pencapaian, petunjuk pengerjaan, ringkasan materi, deskripsi terkait alat dan bahan membatik serta cara membuat batik, dan latihan soal mengenai konsep perbandingan.

\section{Daftar Pustaka}

Hobri. (2008). Model-model Pembelajaran Inovatif. Jember: Universitas Jember.

Soedjadi, R. (2000). Kiat Pendidikan Matematika di Indonesia. Jakarta: Direktorat Jenderal Pendidikan Tinggi Departemen Pendidikan Nasional.

Purba. (2014). Pembuatan Aplikasi Rumus dan Perhitungan Matematika Populer "MATOP" Berbasis Android. Yogyakarta: Sekolah Tinggi Manajemen Informatikadan Komputer.

Suwito, A., \& Trapsilasiwi, D. (2016). Pengembangan Model Pembelajaran MatematikaSMP Kelas VII Berbasis Kehidupan Masyarakat JAWARA (Jawa dan Madura) di Kabupaten Jember. Jurnal Ilmiah Pendidikan Matematika, 79-84.

Tjahjani, I. (2013). Yuk Mbatik! Panduan Terampil Membatik untuk Siswa. Jakarta: Erlangga.

Lestari, I. (2013). Pengembangan Bahan Ajar Berbasis Kompetensi (Sesuai dengan Kurikulum Tingkat Satuan Pendidikan). Padang: Akademia Permata.

Fadillah, U. (2015). Identifikasi Aktivitas Etnomatematika Petani adi Pada Masyarakat Jawa di Desa Setail. J, Kadikama, vol. 6, no. 3, pp, 45-56.

Wahyuni, Indah. (2016). Eksplorasi Etnomatematika Masyarakat Pesisir Selatan Kecamatan Puger Kabtupaten Jember. Fenomena. 15 (2). 225-237.

Hartoyo, Agung. (2012). Eksplorasi Etnomatematika pada Budaya Masyarakat Dayak Perbatasan Indonesia-Malaysia Kabupaten Sanggau Kalbar. Jurnal Penelitian Pendidikan. 13(1):14-23.

Isnawati, L. Z. (2017). Etnomatematika Pada Motif Sulam Usus dalam Bahasan Geometri. Skripsi. Lampung: Fakultas Tarbiyah dan Keguruan Universitas Islam Negeri Raden Intan Lampung.

Arwanto. Eksplorasi Etnomatematika Batik Trusmi Cirebon untuk Mengungkap Nilai Filosofi dan Konsep Matematis. Jurnal. Universitas Muhammadiyah Cirebon. 
Rohma, H. N. (2018). Etnomatematika pada Aktivitas Membatik di Rumah Produksi Rezti's Mboloe Jember. Skripsi. Jember: Fakultas Keguruan dan Ilmu Pendidikan Universitas Jember. 